\title{
Effect of polymorphisms in the ABCG2, LEPR and SCD1 genes on milk production traits in Holstein cows
}

\author{
M. Soltani-Ghombavani, S. Ansari-Mahyari", M. Rostami, \\ S. Ghanbari-Baghenoei \& M.A. Edriss
}

Department of Animal Science, College of Agriculture, Isfahan University of Technology, Isfahan 8415683111, Iran

(Received 5 November 2014; Accepted 13 May 2016; First published online 24 June 2016)

\author{
Copyright resides with the authors in terms of the Creative Commons Attribution 2.5 South African Licence. \\ See: http://creativecommons.org/licenses/by/2.5/za \\ Condition of use: The user may copy, distribute, transmit and adapt the work, but must recognise the authors and the South African \\ Journal of Animal Science.
}

\begin{abstract}
This study was performed to investigate the association between polymorphisms in the ABCG2 (ATPbinding cassette sub-family $\mathrm{G}$ member 2), LEPR (leptin receptor) and SCD1 (stearoyl-coenzyme A desaturase 1) genes and milk production traits in Holstein dairy cows in Iran. The analysis was conducted on 816 lactations from 408 Iranian Holstein cows. Genotyping was carried out using the PCR-RFLP (polymerase chain reaction-restriction fragment length polymorphism) technique. The results of the association study revealed that cows with genotype $A C$ of the ABCG2-Y581S single nucleotide polymorphism (SNP) had lower breeding value for milk yield compared with the AA genotype, but showed significantly higher fat and protein percentages. Cows that were homozygous for allele T at the LEPR-T945M locus had higher breeding value for fat yield than those that were homozygous for the $C$ allele. Regarding the SCD1-A293V SNP, cows with genotype AV produced a higher 305-day milk yield in comparison with cows with the VV genotype. Furthermore, cows that were homozygous for allele $\mathrm{V}$ showed a significantly higher protein percentage compared with AA and AV genotypes. The results of this study suggest that these SNPs have the potential to be used in programmes based on genomic selection in Iranian dairy herds.
\end{abstract}

Keywords: Genetic polymorphism, Iranian Holstein, milk fat, milk protein, SNP

\# Corresponding author: s.ansari@cc.iut.ac.ir

\section{Introduction}

The application of marker-assisted selection has the potential to enhance genetic improvement in livestock by direct selection of genes or genomic regions that affect economic traits through genomic selection (Dekkers \& Hospital, 2002). Individual genes, markers and quantitative trait loci (QTL) can be used to select desirable animals at an early age, based on their genotypes (Banos et al., 2008). Many genes have been chosen as candidates for economically important traits in dairy cattle based on their physiological role in traits of interest or on their being located in genome regions containing previously identified QTLs for these traits. Knowledge of the association between polymorphisms in these candidate genes and traits of economic importance is essential for their effective use in marker-assisted selection. Among candidates for milk production traits, the ABCG2 (ATP-binding cassette sub-family G member 2), LEPR (leptin receptor) and $S C D 1$ (stearoyl-coenzyme A desaturase 1 ) genes seem promising.

$A B C G 2$ is a member of the ATP-binding cassette (ABC) superfamily, which transports various xenobiotics and cytostatic drugs across the plasma membrane (Litman et al., 2000). It has been demonstrated that the $A B C G 2$ is responsible for the active secretion of clinically important substrates into mouse milk, and that mice that are homozygous for an ABCG2 knock-out mutation lack this function (Jonker et al., 2005). The expression of this gene in the mammary gland is increased significantly during lactation, compared with the dry period (Farke et al., 2008). The bovine ABCG2 gene is located in the region of chromosome 6, harbouring a QTL for milk production traits (Olsen et al., 2005). Several genes, including $A B C G 2$, have been proposed as candidates in the QTL region. Analysing the sequence variation of these genes SNP ( $A$ to $C$ ) in exon 14 of the $A B C G 2$, causing the substitution of tyrosine to serine at position 581 (ABCG2-Y581S), has been demonstrated to be the only polymorphism that corresponded to the segregation status of the QTL based on the allele substitution effect (Cohen-Zinder et al., 2005). Using physical mapping and combined linkage disequilibrium mapping, the QTL region between the $A B C G 2$ and $L A P 3$ genes has been fine-mapped and it has been found that the $A B C G 2-Y 581 S$ is the only marker in perfect linkage 
disequilibrium with the QTL (Olsen et al., 2007). The ABCG2-Y581S has been shown to be associated with milk production traits in Polish Holstein-Friesians (Komisarek \& Dorynek, 2009).

Leptin is an important hormone that is involved in feed intake, energy partitioning and metabolism, and consequently has an effect on energy balance and milk production traits (Liefers et al., 2002; Silva et al., 2002). Since this hormone exerts physiological effects through receptors located in most bovine tissues (Silva et al., 2002), the leptin receptor can be regarded as a candidate that influences milk production traits. The LEPR gene is located on bovine chromosome 3 (Pfister-Genskow et al., 1997) and in the proximity of a QTL for milk fat yield (Rodriguez-Zas et al., 2002). This gene produces various leptin receptor isoforms through alternative splicing. The isoforms have identical extracellular domains, and differences between them are due to changes in the length of the intracellular domains. The long form of the receptor (LEPR-b) has the complete cytoplasmic domain and is responsible for most physiological effects of leptin (Tartaglia L.A., 1997). A non-synonymous SNP in exon 20 of the LEPR gene, causing the substitution of threonine with methionine in the intracellular domain of the LEPR at residue 945 (LEPR-T945M), has been shown to affect bovine leptin concentration during pregnancy (Liefers et al., 2004). Furthermore, this SNP has been reported to be associated with milk fat and protein contents (Komisarek \& Dorynek 2006; Suchocki et al., 2010).

The SCD1 gene, located on bovine chromosome 26 (Chung et al., 2000), encodes a key enzyme that introduces a double bond between carbons 9 and 10 of medium to long-chain saturated fatty acids (Corl et al., 2001). This enzyme is also involved in some aspects of metabolism, including lipogenesis and lipid oxidation (Flowers \& Ntambi, 2008). The enzyme is abundantly expressed in the mammary gland of lactating ruminants and plays a major role in the synthesis of milk fat (Bionaz \& Loor, 2008). An SNP in exon 5 of the bovine SCD1, which causes the replacement of valine with alanine at residue 293 (SCD1-A293V), has been reported to be associated with milk fatty acid composition in various cattle populations (Mele et al., 2007; Schennink et al., 2008; Kgwatalala et al., 2009). However, literature that reports a significant effect of this polymorphism on milk production traits is limited, though an effect of this SNP on milk and protein yield has been described in Italian Holsteins (Macciotta et al., 2008) and Canadian Jerseys (Kgwatalala et al., 2009). The objective of this study was therefore to examine the effect of polymorphisms in the ABCG2, LEPR and $S C D 1$ genes on milk production traits in Iranian Holstein dairy cattle to provide useful markers for these traits in genetic selection programmes.

\section{Materials and Methods}

A total of 816 lactations from 408 Iranian Holstein cows (with a major genetic influence from USA and Canada) by 155 bulls ( 1 to 24 progeny per bull) were analysed in this study. The cows were randomly selected from five dairy herds in the Isfahan Province of Iran. Accurate phenotypic data for 305-day milk yield, fat and protein percentage, somatic cell count (SCC), and breeding value data (from national evaluations) for fat and milk yield were obtained from the Vahdat Industrial Agriculturists \& Dairymen Cooperative of Isfahan Province in the centre of Iran, which hosts the biggest milk production herds across the country. Intensive production systems using open-shed and free-stall barns are the predominant housing systems. Most of the farms use feed rations that are relatively high in concentrates, with alfalfa and corn silage as the major roughage. Cows are milked three times a day. On average, Iranian Holstein cows produce $9000 \mathrm{~kg}$ milk, $300 \mathrm{~kg}$ fat and $270 \mathrm{~kg}$ protein in a 305-day lactation. SCC was transformed to somatic cell score (SCS) for each record (SCS $=\log _{2}[S C C / 100000]+3$ ) to achieve normality and homogeneity of variances. Blood samples for DNA extraction were collected using vacuum venoject tubes containing EDTA and stored at $-20^{\circ} \mathrm{C}$ until DNA extraction.

Genomic DNA was extracted from blood samples by the salting-out method (Miller et al., 1988). Genotypes were determined using the PCR-RFLP technique. PCR was used to amplify the DNA fragments containing the polymorphisms of interest. The PCR reactions were carried out in a total volume of $20 \mu \mathrm{L}$, which contained $50 \mathrm{ng}$ genomic DNA, 10 pmoL each primer, $2 \mu \mathrm{L} 10 \mathrm{X}$ PCR buffer, $2 \mathrm{mM} \mathrm{MgCl} 2,200 \mu \mathrm{M}$ dNTPs and 2.5 units Taq DNA polymerase (Fermentas, Germany). Sequences of the primers used in the PCR for the fragments containing LEPR-T945M, ABCG2-Y581S and SCD1-A293V were as presented in Table 1 (Komisarek \& Dorynek, 2006; Kgwatalala et al., 2009; Komisarek \& Dorynek, 2009).

Thermal cycling conditions were as follows: initial denaturation at $94^{\circ} \mathrm{C}$ for $2 \mathrm{~min}, 35$ cycles of denaturation at $94^{\circ} \mathrm{C}$ for $30 \mathrm{~s}$, annealing temperature (Table 1) for $1 \mathrm{~min}$, extension at $72{ }^{\circ} \mathrm{C}$ for $1 \mathrm{~min}$, and a final extension at $72^{\circ} \mathrm{C}$ for $10 \mathrm{~min}$.

The PCR products were digested with $5 \mathrm{U}$ (Table 1) restriction enzymes (Fermentas, Germany), in 20 $\mu \mathrm{L}$ of reaction volume for $8 \mathrm{~h}$ at 37 and $60^{\circ} \mathrm{C}$ for the fragments containing the ABCG2-Y581S and LEPRT945M, respectively, then subjected to electrophoretic separation in $2.5 \%$ ethidium bromide-stained agarose gel. The A allele of the ABCG2-Y581S polymorphism was characterized by a single 292-bp fragment, while the $\mathrm{C}$ allele was identified by the presence of two fragments of 268 and $24 \mathrm{bp}$. For the LEPR-T945M locus, the $T$ allele was determined by a fragment of $400 \mathrm{bp}$ and the $C$ allele resulted in two fragments of 375 and 
$25 \mathrm{bp}$. Furthermore, allele A of the SCD1-A293V was characterized by a fragment of $200 \mathrm{bp}$, while the V allele was determined by a 400-bp fragment. Tests of Hardy-Weinberg equilibrium for each locus were conducted separately using the software POPGENE (Yeh et al., 2000).

Table 1 Primers and PCR-RFLP conditions used for the analysed polymorphisms

\begin{tabular}{|c|c|c|c|c|}
\hline SNP & Primers (5'-3') & $\begin{array}{l}\text { Annealing } \\
\text { temp }\left({ }^{\circ} \mathrm{C}\right)\end{array}$ & $\begin{array}{l}\text { Restriction } \\
\text { enzyme }\end{array}$ & $\begin{array}{c}\text { Digestion } \\
\text { product size } \\
\text { (bp) }\end{array}$ \\
\hline ABCG2-Y581S & $\begin{array}{l}\text { F-AACAGCCTCAGCTCCAGAGAGATAT } \\
\text { R-CGGTGACAGATAAGGAGAACATACT }\end{array}$ & 57 & Pstl & $\begin{array}{l}\text { A : } 292 \\
\text { C : } 268,24\end{array}$ \\
\hline LEPR-T945M & $\begin{array}{l}\text { F-GCAACTACAGATGCTCTACTTTTGT } \\
\text { R-CAGGGAAATTTCCCTCAAGTTTCAA }\end{array}$ & 60 & Taq & $\begin{array}{l}T: 400 \\
C: 375,25\end{array}$ \\
\hline SCD1-A293V & $\begin{array}{l}\text { F-CCCATTCGCTCTTGTTCTGT } \\
\text { R-CGTGGTCTTGCTGTCGACT }\end{array}$ & 59 & Ncol & $\begin{array}{l}V: 400 \\
A: 200\end{array}$ \\
\hline
\end{tabular}

SNP: single nucleotide polymorphism.

For the association studies, the traits of interest were analysed using the least squares method of the general linear model (GLM) procedure of SAS software [SAS, Version 8] according to the following model:

where:

$$
\mathrm{Y}_{\mathrm{ijk} \mid m n o}=\mu+\mathrm{A}_{\mathrm{i}}+\mathrm{L}_{\mathrm{j}}+\mathrm{S}_{\mathrm{k}}+\mathrm{HYS}_{\mathrm{I}}+\mathrm{L}_{\mathrm{m}}+\mathrm{S}_{\mathrm{n}}+\mathrm{b}_{1}\left(\mathrm{X}_{\mathrm{ijk} k m n o}-\bar{X}\right)+\mathrm{b}_{2}\left(\mathrm{~W}_{\mathrm{ijk} \mid m n o}-\bar{W}\right)+\mathrm{e}_{\mathrm{ijk} \mid m n o}
$$

$Y_{\mathrm{ijk} k m n o}=$ value for each trait 305-day milk yield, fat and protein percentage, somatic cell score, and breeding value for fat and milk yield; $\mu=$ overall mean;

$A_{i}=$ fixed effect of genotype $A B C G 2 ; L_{j}=$ fixed effect of genotype $L E P R$;

$S_{k}=$ fixed effect of genotype $S C D 1 ; H Y S_{1}=$ combined effect of herd, year and season of parturition;

$\mathrm{L}_{\mathrm{m}}=$ fixed effect of lactation number; $\mathrm{S}_{\mathrm{n}}=$ random effect of sire;

$\mathrm{b}_{1}=$ regression coefficient of milk yield; $\mathrm{X}_{\mathrm{ijk} \text { mno }}=$ milk yield; $\bar{X}=$ mean of milk yield;

$\mathrm{b}_{2}=$ regression coefficient of open days; $\mathrm{W}_{\mathrm{ijk} k \mathrm{mno}}=$ open days; $\bar{W}=$ mean of open days;

$\mathrm{e}_{\mathrm{ijk} \mid \mathrm{mno}}=$ random residual effect.

For the analysis of 305-day milk yield, milk yield as a covariate was excluded from the model. Also, wherever breeding value was used instead of phenotypic value for a trait, effects other than genotype were omitted from the model. The average allele substitution effect of each SNP was estimated by regressing the number of copies of each allele against the phenotypic or breeding value for each trait (Sherman et al., 2008).

\section{Results and Discussion}

All known SNP alleles of the ABCG2-Y581S (A and C), LEPR-T945M (T and C) and SCD1-A293V (A and $\mathrm{V}$ ) polymorphisms were observed in this study (Table 2).

As a result of a very low frequency of the $C$ allele of the $A B C G 2-Y 581 S$ locus, the $C C$ genotype of this locus was not detected within the population. A much higher frequency of the A variant of the ABCG2-Y581S compared with the $C$ variant in the current study ( $97 \%$ vs. $3 \%)$ is in agreement with previous reports. A high frequency of the A allele was reported in Israeli Holstein-Friesians (Cohen-Zinder et al., 2005). The same tendency was reported in 32 Bos taurus and three Bos indicus breeds (Ron et al., 2006). The A variant was found to be fixed in Indian cattle and buffalo breeds (Tantia et al., 2006). A higher frequency for the A allele of this SNP than the C allele was reported in Norwegian Red cattle (Olsen et al., 2002). Furthermore, a higher frequency of the $A$ variant of $A B C G 2-Y 581 S$ compared with the $C$ variant was evident in Polish Holstein-Friesian bulls (Komisarek \& Dorynek, 2009). The higher frequency of the C allele of LEPR-T945M, compared with the T allele (65\% vs. $35 \%$ ), in the study population of Iranian Holstein cows confirms earlier studies on Holstein-Friesian cows (Liefers et al., 2004), Jersey cows (Komisarek \& Dorynek, 2006), Polish dairy population (Szyda \& Komisarek, 2007), UK Holstein cows (Banos et al., 2008), Polish Holstein-Friesian cattle (Komisarek, 2010), Jersey and Polish Holstein-Friesian cows (Suchocki et al., 2010) and Swedish Red and Swedish Holstein cows (Glantz et al., 2011; Glantz et al., 2012). Nevertheless, except for Jersey cows (Suchocki et al., 2010), the frequency for the C allele obtained in the current study was lower than those reported by these authors. Similar to previous reports (Asadollahpour Nanaei et al., 2013), the frequencies for the $\mathrm{A}$ and $\mathrm{V}$ alleles of the SCD1-A293V polymorphism in the current study were 0.58 and 0.42 , 
respectively. Consistent with results from the present study, a higher frequency of the $A$ allele in comparison with the $\mathrm{V}$ allele has been reported in Japanese Black cattle (Taniguchi et al., 2004), Italian Holstein (Mele et al., 2007), Valdostana breed (Moioli et al., 2007) and Canadian Jersey (Kgwatalala et al., 2009). On the contrary, in the Piedmontese breed (Moioli et al., 2007) and Italian Brown cattle (Conte et al., 2010) the V allele had a higher frequency compared with the $A$ allele. The result of the test for Hardy-Weinberg equilibrium for the loci ABCG2-Y581S and LEPR-T945M did not show significant deviation from HardyWeinberg equilibrium (Table 2). However, for the SCD1-A293V, the population of the current study was not in Hardy-Weinberg equilibrium $(P<0.01)$, which indicates non-random mating with respect to this locus in Iranian Holstein cows.

The results of analysis of association between the SNPs and traits of interest and allele substitution effects are presented in Tables 3 and 4, respectively.

Table 2 Allele and genotype frequencies of the ABCG2-Y581S and LEPR-T945M polymorphisms in Iranian Holstein cows

\begin{tabular}{|c|c|c|c|c|c|}
\hline SNP & Allele & Frequency & Genotype & Frequency & Chi-square \\
\hline \multirow{4}{*}{$A B C G 2-Y 581 S$} & $A$ & 0.97 & $A A$ & $0.94(25)$ & \\
\hline & $\mathrm{C}$ & 0.03 & $A C$ & 0.06 & 0.40 \\
\hline & & & $\mathrm{CC}$ & - & \\
\hline & $\mathrm{T}$ & 0.35 & TT & 0.11 & \\
\hline \multirow[t]{2}{*}{ LEPR-T945M } & C & 0.65 & $\mathrm{TC}$ & 0.49 & 1.64 \\
\hline & & & $\mathrm{CC}$ & 0.40 & \\
\hline \multirow{2}{*}{ SCD1-A293V } & A & 0.58 & & & $46.08^{\star \star}$ \\
\hline & $\mathrm{V}$ & 0.42 & & & \\
\hline
\end{tabular}

** Significant at $P<0.01$; SNP: single nucleotide polymorphism.

Table 3 Results of association analysis between the investigated single nucleotide polymorphisms (SNPs) and milk production traits in Iranian Holstein cows (least squares means $\pm \mathrm{SE}$ ).

\begin{tabular}{ll|cccccc}
\hline \multirow{2}{*}{ Genotype } & & \multicolumn{5}{c}{ Trait } \\
\cline { 3 - 8 } & & 305-d MY & BV for MY & BV for FY & FP & PP & SCS \\
\hline \multirow{2}{*}{ ABCG2- } & AA $(n=766)$ & $10114.26 \pm 138.42$ & $530.17 \pm 33.84^{\mathrm{B}}$ & $12.66 \pm 1.19$ & $3.20 \pm 0.05^{\mathrm{A}}$ & $3.03 \pm 0.02^{\mathrm{A}}$ & $1.94 \pm 0.08$ \\
Y581S & AC $(\mathrm{n}=50)$ & $9618.99 \pm 321.19$ & $247.12 \pm 94.39^{\mathrm{A}}$ & $12.26 \pm 3.31$ & $3.49 \pm 0.11^{\mathrm{B}}$ & $3.10 \pm 0.04^{\mathrm{B}}$ & $1.98 \pm 0.17$ \\
\hline & TT $(\mathrm{n}=86)$ & $9831.07 \pm 275.03$ & $453.99 \pm 82.29$ & $16.16 \pm 2.88^{\mathrm{A}}$ & $3.34 \pm 0.09$ & $3.06 \pm .03$ & $1.83 \pm 0.16$ \\
LEPR- & TC $(\mathrm{n}=384)$ & $9837.13 \pm 201.24$ & $383.94 \pm 56.73$ & $11.86 \pm 1.99^{\mathrm{AB}}$ & $3.36 \pm 0.07$ & $3.07 \pm 0.02$ & $2.06 \pm 0.11$ \\
T945M & CC $(\mathrm{n}=320)$ & $9931.66 \pm 208.46$ & $328.01 \pm 56.07$ & $9.35 \pm 1.96^{\mathrm{B}}$ & $3.33 \pm 0.07$ & $3.07 \pm 0.02$ & $1.99 \pm 0.11$ \\
\hline & AA $(\mathrm{n}=212)$ & $9607.13 \pm 204.74^{\mathrm{A}}$ & $341.59 \pm 62.30$ & $11.02 \pm 2.18$ & $3.31 \pm 0.07$ & $3.03 \pm 0.02^{\mathrm{A}}$ & $1.97 \pm 0.12$ \\
SCD1- & AV $(\mathrm{n}=530)$ & $10086.36 \pm 190.86^{\mathrm{B}}$ & $388.74 \pm 53.14$ & $13.73 \pm 1.86$ & $3.29 \pm 0.06$ & $3.00 \pm 0.02^{\mathrm{A}}$ & $2.07 \pm 0.10$ \\
A293V & VV $(\mathrm{n}=74)$ & $9906.37 \pm 311.22^{\mathrm{AB}}$ & $435.61 \pm 85.77$ & $12.63 \pm 3.00$ & $3.44 \pm 0.11$ & $3.17 \pm 0.04^{\mathrm{B}}$ & $1.84 \pm 0.18$ \\
& & & & & & &
\end{tabular}

305-d MY: 305-day milk yield; BV: breeding value; MY: milk yield; FY: fat yield; FP: fat percentage; PP: protein percentage; SCS: somatic cell score.

$A, \mathrm{~B}$ Means within a row with different superscripts differ significantly at $P<0.05$.

The polymorphism in the ABCG2 gene was found to be significantly associated with breeding value for milk yield, and fat and protein percentages. The substitution of the A allele for the $C$ allele increased the percentages of fat and protein by $0.29 \%$ and $0.07 \%$, respectively, and decreased milk yield by $278.09 \mathrm{~kg}$, 
Table 4 Estimates of the allele substitution effects of the investigated single nucleotide polymorphisms (SNPs) for milk production traits in Iranian Holstein cows

\begin{tabular}{|c|c|c|}
\hline Trait & $\begin{array}{c}\text { Allele substitution } \\
\text { effects }\end{array}$ & $P$-value \\
\hline & \multicolumn{2}{|c|}{ ABCG2-Y581S (C vs. A) } \\
\hline 305-d MY & $-511.23 \pm 295.52$ & 0.084 \\
\hline BV for MY & $-278.09 \pm 93.27^{* *}$ & 0.003 \\
\hline BV for FY & $-0.18 \pm 3.26$ & 0.957 \\
\hline FP & $0.29 \pm 0.10^{* *}$ & 0.003 \\
\hline PP & $0.07 \pm 0.03^{*}$ & 0.027 \\
\hline \multirow[t]{2}{*}{ SCS } & $0.18 \pm 0.21$ & 0.395 \\
\hline & \multicolumn{2}{|c|}{ LEPR-T945M (T vs. C) } \\
\hline 305-d MY & $-68.90 \pm 99.65$ & 0.490 \\
\hline BV for MY & $67.01 \pm 34.66^{*}$ & 0.054 \\
\hline$B V$ for $F Y$ & $3.80 \pm 1.20 * *$ & 0.002 \\
\hline FP & $0.03 \pm 0.03$ & 0.332 \\
\hline PP & $0.01 \pm 0.01$ & 0.600 \\
\hline \multirow[t]{2}{*}{ SCS } & $-0.05 \pm 0.10$ & 0.588 \\
\hline & \multicolumn{2}{|c|}{ SCD1-A293V (V vs. A) } \\
\hline 305-d MY & $290.52 \pm 123.11^{*}$ & 0.019 \\
\hline BV for MY & $47.51 \pm 39.19$ & 0.226 \\
\hline BV for FY & $1.53 \pm 1.37$ & 0.266 \\
\hline FP & $0.03 \pm 0.04$ & 0.540 \\
\hline PP & $0.02 \pm 0.01$ & 0.083 \\
\hline SCS & $-0.04 \pm 0.07$ & 0.598 \\
\hline
\end{tabular}

* Significant at $P<0.05$; * Significant at $P<0.01$.

305-d MY: 305-day milk yield; BV: breeding value; MY: milk yield;

FY: fat yield; FP: fat percentage; PP: protein percentage;

SCS $=$ somatic cell score.

(Table 4). Cows with the $A C$ genotype had a significantly lower breeding value for milk yield than those with the AA genotype $(P<0.01)$. The AC genotype had higher fat $(P<0.01)$ and protein $(P<0.05)$ percentages than those of the AA genotype. In line with these results, the effect of this SNP on these traits has been reported in other studies, though opposite effects were observed for the alleles $C$ and $A$ in the current research compared with these studies (Cohen-Zinder et al., 2005; Olsen et al., 2007). These studies found a negative effect of the A allele on fat and protein percentages and a positive effect on milk yield in Israeli Holstein-Friesians and Norwegian Red cattle, respectively. Interestingly, the allele substitution effect of 278.1 $\mathrm{kg}$ milk yield obtained in the current study was consistent with those reported by Cohen-Zinder et al. (2005). Nevertheless, the allele substitution effect for fat percentage $(0.29 \%)$ was approximately half of that estimated by Cohen-Zinder et al. (2005). Moreover, for protein percentage, the allele substitution effect in this study (0.07\%) was two times those reported by Cohen-Zinder et al. (2005). Also, an association of the A variant with higher fat and protein percentages, but not with milk yield, was reported in Polish HolsteinFriesian bulls (Komisarek \& Dorynek, 2009). Contrary to the researchers' findings, Cohen-Zinder et al. (2005) and Komisarek \& Dorynek (2009) have found an association between the A allele and breeding value for fat yield. No significant association was evident between the genotypes of the ABCG2-Y581S and 305-day milk yield, breeding value for fat yield and SCS in the current study $(P>0.05)$. The differences between these results in the associations and values for the allele substitution effects may be attributed to a lack of $C C$ individuals and a very low number of $A C$ animals among the populations.

The LEPR-T945M polymorphism in the present study showed only a significant association with breeding value for fat yield. Cows carrying the genotype TT were found to be superior in this trait than those carrying the CC genotype $(P<0.05)$. As shown in Table 4 , replacing the $C$ allele with the $T$ allele increased 
fat yield by $3.80 \mathrm{~kg}$. The results of other studies (Komisarek \& Dorynek, 2006; Suchocki et al., 2010; Glantz et al., 2012) revealed no relationship between this SNP and fat yield. This association implies that the SNP may be in linkage disequilibrium with a gene engaged in milk fat synthesis or may be the possible role of LEPR in milk fat synthesis which can be considered in marker-assisted selection for improving this trait. The association of this polymorphism with fat yield in the current study may be attributed to the physiological actions of the hormone, leptin, through its receptor. The LEPR-T945M was revealed to be correlated with the plasma leptin concentration, which might influence the signal transduction pathway of the hormone (Liefers et al., 2004). In the presence of prolactin, leptin has been shown to increase fatty acid synthesis in the mammary gland (Feuermann et al., 2004). Furthermore, in support of the authors' hypothesis, it has been demonstrated that leptin, acting through its receptor, modulates some functions of DGAT1 (Chen et al., 2002) as a key enzyme in triacylglycerol synthesis (Schennink et al., 2008), though the underlying physiological mechanisms remain unclear. The threonine $\rightarrow$ methionine amino acid substitution in the intracellular domain of LEPR may change its signalling capability. Hence, the LEPR-T945M can be supposed to be the causal mutation underlying the QTL affecting fat yield mapped in close vicinity of the LEPR gene (Rodriguez-Zas et al., 2002). In contrast, an effect of this polymorphism on fat and protein percentages was reported in Jersey cows (Komisarek \& Dorynek, 2006). In that study, animals with the TT genotype were characterized by the lowest values for both traits. Similarly, an association of this polymorphism with fat and protein percentages was found in Jersey and Polish Holstein-Friesian, respectively (Suchocki et al., 2010). Interestingly, opposite effects were observed for fat percentage in Holstein-Friesians (allele C increased fat content) and in Jerseys (allele $\mathrm{C}$ decreased fat content) in the latter study. In agreement with the researchers' results, no association of the LEPR-T945M with fat percentage (Glantz et al., 2011; Glantz et al., 2012), protein percentage (Glantz et al., 2011; Glantz et al., 2012), milk yield (Komisarek \& Dorynek, 2006; Banos et al., 2008; Suchocki et al., 2010; Glantz et al., 2011; Glantz et al., 2012) and SCS (Komisarek, 2010) was reported in various cattle populations.

The current study indicated an effect of the SCD1-A293V genotype on 305-day milk yield. Animals of the AA genotype had lower 305-day milk yield in comparison with those of genotype AV $(P<0.01)$. As presented in Table 4, substituting the A allele with the $V$ allele increased 305-day milk yield by $290.5 \mathrm{~kg}$. Association of the SCD1-A293V with 305-day milk yield in the present study was in line with the results from a study on Italian Holsteins with a higher milk yield for the VV genotype than the AA genotype (Macciotta et al., 2008). In contrast, a positive effect of the A allele on increased 305-d milk yield was revealed in a Canadian Jersey population (Kgwatalala et al., 2009). Contrary to the current study, no significant effect of this SNP on milk yield was found in Dutch Holstein-Friesian (Schennink et al., 2008), Polish Holstein-Friesian (Komisarek \& Dorynek, 2009) and four breeds of Friesian, Jersey, Piedmontese and Valdostana (Signorelli et al., 2009), respectively. The current result also revealed an effect of the SCD1-A293V polymorphism on protein percentage. Cows homozygous for the $\mathrm{V}$ allele showed higher protein percentage in their milk compared with the AA and AV genotypes $(P<0.01)$ and substituting the $A$ allele with the $V$ allele increased protein percentage by $0.02 \%$ (Table 4). Findings of other studies showed no association of the SNP with this trait (Schennink et al., 2008; Kgwatalala et al., 2009; Komisarek \& Dorynek, 2009; Signorelli et al., 2009). However, an effect of this polymorphism on protein yield was reported in a Canadian Jersey population (Kgwatalala et al., 2009) and in Italian Holsteins (Macciotta et al., 2008). Several studies have mapped QTLs for milk yield and composition traits on chromosome 26 and in close proximity of the SCD1 gene (Plante et al., 2001; Boichard et al., 2003; Jiang et al., 2005). It can therefore be postulated that the SCD1-A293V SNP may be the causal mutation or a marker in linkage disequilibrium with an unknown causal mutation underlying the QTLS. No significant relationship was found between the SCD1-A293V genotypes and breeding value for milk and fat yield, fat percentage and SCS $(P>0.05)$. Similar to the current findings, no association has been reported between the SCD1-A293V and fat yield and percentage (Macciotta et al., 2008; Schennink et al., 2008; Kgwatalala et al., 2009; Komisarek \& Dorynek, 2009; Signorelli et al., 2009) and SCS (Komisarek \& Dorynek, 2009).

\section{Conclusions}

In conclusion, the present study demonstrated the association of polymorphisms at the ABCG2Y581S, LEPR-T945M and SCD1-A293V loci with milk production traits in Iranian Holstein population. The C variant of the $A B C G 2-Y 581 S$ was associated with higher fat and protein percentages and lower milk yield. Furthermore, the T allele of the LEPR-T945M showed a significant effect on increased fat yield. Additionally, the $\mathrm{V}$ allele of the SCD1-A293V was revealed to be associated with higher 305-day milk yield and protein percentage. Regarding the associations reported in this study, these three polymorphisms have the potential to be used as quantitative trait nucleotides (QTNs) for selection in favour of these traits through genomic selection. 


\section{Acknowledgement}

The authors gratefully thank Isfahan University of Technology for supporting this research financially. The authors also acknowledge the Vahdat Industrial Agriculturists \& Dairymen Cooperative of Isfahan province of Iran for supplying data for milk-related traits.

\section{Authors' contributions}

MS-G analysed the data and prepared the manuscript with contributions from other co-authors. SA-M supervised the experiment. MR and SG-B designed and carried out the experiment. MAE supervised the experiment.

\section{Conflict of interest declaration}

The authors declare that the research was conducted in the absence of any commercial or financial relationships that could be construed as a potential conflict of interest.

\section{References}

Asadollahpour Nanaei, H., Ansari Mahyari, S., Edriss, M.A., Pirzad, M. \& Boroushak, A., 2013. Polymorphism of SCD1 and DGAT1 gene in Isfahan Holstein cows. IJABBR. 1, 783-788.

Banos, G., Woolliams, J.A., Woodward, B.W., Forbes, A.B. \& Coffey, M.P., 2008. Impact of single nucleotide polymorphisms in leptin, leptin receptor, growth hormone receptor, and diacylglycerol acyltransferase (DGAT1) gene loci on milk production, feed, and body energy traits of UK dairy cows. J. Dairy Sci. 91, 3190-3200.

Bionaz, M. \& Loor, J.J., 2008. Gene networks driving bovine milk fat synthesis during the lactation cycle. BMC Genomics $9,366$.

Boichard, D., Grohs, C., Bourgeois, F., Cerqueira, F. \& Faugeras, R., 2003. Detection of genes influencing economic traits in three French dairy cattle breeds. Genet. Sel. Evol. 35, 77-101.

Chen, H.C., Smith, S.J., Tow, B., Elias, P.M. \& Farese, R.V.J.R., 2002. Leptin modulates the effects of acyl CoA:diacylglycerol acyltransferase deficiency on murine fur and sebaceous glands. J. Clin. Invest. 109, 175-181.

Chung, M., Ha, S., Jeong, S., Bok, J., Cho, K., Baik, M. \& Choi, Y., 2000. Cloning and characterization of bovine stearoyl CoA desaturase I cDNA from adipose tissues. Biosci. Biotechnol. Biochem. 64, 1526-1530.

Cohen-Zinder, M., Seroussi, E., Larkin, D.M., Loor, J.J., Everst-Van Der Wind, A., Lee, J.H., Drackley, J.K., Band, M.R., Hernandez, A.G., Shani, M., Lewin, H.A., Weller, J.I. \& Ron, M., 2005. Identification of a missense mutation in the bovine ABCG2 gene with a major effect on the QTL on chromosome 6 affecting milk yield and composition in Holstein cattle. Genome Res. 15, 936-44.

Conte, G., Mele, M., Chessa, S., Castiglioni, B., Serra, A., Pagnacco, G. \& Secchiari, P., 2010. Diacylglycerol acyltransferase 1 , stearoyl-CoA desaturase 1 , and sterol regulatory element binding protein 1 gene polymorphisms and milk fatty acid composition in Italian Brown cattle. J. Dairy Sci. 93, 753-763.

Corl, B.A., Baumgard, L.H., Dwyer, D.A., Griinari, J.M., Phillips, B.S. \& Bauman, D.E., 2001. The role of $\Delta 9$-desaturase in the production of cis-9, trans-11 CLA. J. Nutr. Biochem. 12, 622-630.

Dekkers, J.C.M. \& Hospital, F., 2002. The use of molecular genetics in the improvement of agricultural populations. Nat. Rev. Genet. 3 (1), 22-32.

Farke, C., Meyer, H.H., Bruckmaier, R.M. \& Albrecht, C., 2008. Differential expression of ABC transporters and their regulatory genes during lactation and dry period in bovine mammary tissue. J. Dairy Res. 75, 406-414.

Feuermann, Y., Mabjeesh, S.J. \& Shamay, A., 2004. Leptin affects prolactin action on milk protein and fat synthesis in the bovine mammary gland. J. Dairy Sci. 87, 2941-2946.

Flowers, M.T. \& Ntambi, J.M., 2008. Role of stearoyl-coenzyme A desaturase in regulating lipid metabolism. Curr. Opin. Lipidol. 19, 248-256.

Georges, M., Nielsen, D., Mackinnon, M., Mishra, A., Okimoto, R., Pasquino, A.T., Sargeant, L.S., Sorenson, A., Steele, M.R. \& Zhao, X., 1995. Mapping quantitative trait loci controlling milk production in dairy cattle by exploiting progeny testing. Genetics $139,907-920$.

Glantz, M., Lindmark Mansson, H., Stalhammar, H. \& Paulsson, M., 2011. Effect of polymorphisms in the leptin, leptin receptor, and acyl-coenzyme A: diacylglycerol acyltransferase 1 (DGAT1) genes and genetic polymorphism of milk proteins on cheese characteristics. J. Dairy Sci. 94, 3295-3304.

Glantz, M., Lindmark Mansson, H., Stalhammar, H. \& Paulsson, M., 2012. Effect of polymorphisms in the leptin, leptin receptor and acyl-CoA: diacylglycerol acyltransferase 1 (DGAT1) genes and genetic polymorphism of milk proteins on bovine milk composition. J. Dairy Res. 79, 110-118.

Jiang, Z., De, S., Garcia, M.D., Griffin, K.B., Wu, X.L., Xiao, Q., Michal, J.J., Sharma, B.S. \& Jansen, G.B., 2005. An independent confirmation of a quantitative trait locus for milk yield and composition traits on bovine chromosome 26. J. Anim. Breed. Gen. 122, 281-284.

Jonker, J.W., Merino, G., Musters, S., Van Heraarden, A.E., Bolscher, E., Wagenaar, E., Mesman, E., Dale, T.C. \& Schinkel, A.H., 2005. The breast cancer resistance protein BCRP (ABCG2) concentrates drugs and carcinogenic xenotoxins into milk. Nat. Med. 11, 127-129.

Kgwatalala, P.M., leagha-Awamu, E.M., Mustafa, A.F. \& Zhao, X., 2009. Influence of stearoyl-coenzyme A desaturase 1 genotype and stage of lactation on fatty acid composition of Canadian Jersey cows. J. Dairy Sci. 92, 1220-1228.

Khatkar, M.S., Thompson, P.C., Tammen, I. \& Raadsma, H.W., 2004. Quantitative trait loci mapping in dairy cattle: review and meta-analysis. Genet. Sel. Evol. 36, 163-190.

Komisarek, J., 2010. Impact of LEP and LEPR gene polymorphisms on functional traits in Polish Holstein-Friesian cattle. Anim. Sci. Pap. Rep. 28, 133-141. 
Komisarek, J. \& Dorynek, Z., 2006. The relationship between the T945M single nucleotide polymorphism in the leptin receptor gene (LEPR) and milk production traits in Jersey cows. Anim. Sci. Pap. Rep. 24, 271-277.

Komisarek, J. \& Dorynek, Z., 2009. Effect of ABCG2, PPARGC1A, OLR1 and SCD1 gene polymorphism on estimated breeding values for functional and production traits in Polish Holstein-Friesian bulls. J. Appl. Genet. 50, 125-132.

Kuhn, C., Freyer, G., Weikard, R., Goldammer, T. \& Schwerin, M., 1999. Detection of QTL for milk production traits in cattle by application of a specifically developed marker map of BTA6. Anim. Genet. 30, 333-340.

Liefers, S.C., Te Pas, M.F., Veerkamp, R.F. \& Van der Lende, T., 2002. Associations between leptin gene polymorphisms and production, live weight, energy balance, feed intake, and fertility in Holstein heifers. J. Dairy Sci. 85, 1633-1638.

Liefers, S.C., Veerkamp, R.F., Te Pas, M.F., Delavaund, C., Chilliard, Y. \& Van der Lende, T., 2004. A missense mutation in the bovine leptin receptor gene is associated with leptin concentrations during late pregnancy. Anim. Genet. 35, 138-141.

Litman, T., Brangi, M., Hudson, E., Fetch, P., Abati, A., Ross, D.D., Miyake, K., Resau, J.H. \& Bates, S.E., 2000. The multidrug-resistant phenotype associated with overexpresion of the new ABC half-transporter, MXR (ABCG2). J. Cell. Sci. 113, 2011-2021.

Macciotta, N.P., Mele, M., Conte, G., Serra, A., Cassandro, M., Dal Zotto, R., Borlino, A.C., Pagnacco, G. \& Secchiari, P., 2008. Association between a polymorphism at the stearoyl CoA desaturase locus and milk production traits in Italian Holsteins. J. Dairy Sci. 91, 3184-3189.

Mele, M., Conte, G., Castiglioni, B., Chessa, S., Macciotta, N.P., Serra, A., Buccioni, A., Pagnacco, G. \& Secchiari, P., 2007. Stearoyl-CoA desaturase gene polymorphism and milk fatty acid composition in Italian Friesian cows. J. Dairy Sci. 90, 4458-4465.

Miller, S.A., Dykes, D.D. \& Polesky, H.F., 1988. A simple salting out procedure for extracting DNA from human nucleated cells. Nucleic Acids Res. 16, 1215.

Moioli, B., Contarini, G., Avalli, A., Cavillo, G., Orr, L., De Matteis, G., Masoero, G. \& Napoletano, F., 2007. Effect of stearoyl coenzyme A desaturase polymorphism on fatty acid composition of milk. J. Dairy Sci. 90, 3553-3558.

Nadesalingam, J., Plante, Y. \& Gibson, J.P., 2001. Detection of QTL for milk production on Chromosomes 1 and 6 of Holstein cattle. Mamm. Genome. 12, 27-31.

Olsen, H.G., Gomez-Raya, L., Vage, D.I., Olsaker, I., Klungland, H., Svendsen, M., Adnoy, T., Sabry, A., Klemetsdal, G., Schulman, N., Kramer, W., Thaller, G., Ronningen, K. \& Lien, S., 2002. A genome scan for quantitative trait loci affecting milk production in Norwegian dairy cattle. J. Dairy Sci. 85, 3124-3130.

Olsen, H.G., Lien, S., Gautier, M., Nilsen, H., Roseth, A., Berg, P.R., Sundaasen, K.K., Svendsen, M. \& Meuwissen, T.H., 2005. Mapping of a milk production quantitative trait locus to a 420-kb region on bovine chromosome 6 . Genetics 169, 275-283.

Olsen, H.G., Nilsen, H., Hayes, B., Berg, P.R., Svendsen, M., Lien, S. \& Meuwissen, T., 2007. Genetic support for a quantitative trait nucleotide in the ABCG2 gene affecting milk composition of dairy cattle. BMC Genomics 8, 32.

Pfister-Genskow, M., Hayes, H., Eggen, A. \& Bishop, M.D., 1997. The leptin receptor (LEPR) gene maps to bovine chromosome 3q33. Mamm. Genome 8, 227.

Plante, Y., Gibson, J.P., Nadesaingam, J., Mehrabani-Yeganeh, H. \& Lefebvre, S., 2001. Detection of quantitative trait loci affecting milk production traits on 10 chromosomes in Holstein cattle. J. Dairy Sci. 84, 1516-1524.

Rodriguez-Zas, S.L., Southey, B.R., Heyen, D.W. \& Lewin H.A., 2002. Interval and composite interval mapping of somatic cell score, yield, and components of milk in dairy cattle. J. Dairy Sci. 85, 3081-3091.

Ron, M., Cohen-Zinder, M., Peter, C., Weller, J.I. \& Erhardt, G., 2006. A polymorphism in ABCG2 in Bos indicus and Bos taurus cattle breeds. J Dairy Sci. 89, 4921-4923.

Schennink, A., Heck, J.M., Bovenhuis, H., Visker, M.H., Van Valenberg, H.J. \& Van Arendonk, J.A., 2008. Milk fatty acid unsaturation: Genetic parameters and effects of stearoyl-CoA desaturase (SCD1) and acyl CoA: diacylglycerol acyltransferase 1 (DGAT1). J. Dairy Sci. 91, 2135-2143.

Sherman, E.L., Nkruman, J.D., Murdoch, B.M., Li, C., Wang, Z., Fu, A. \& Moore, S.S., 2008. Polymorphisms and haplotypes in the bovine NPY, GHR, GHRL, IGF2, UCP2, and UCP3 genes and their associations with measures of growth, performance, feed efficiency and carcass merit in beef cattle. J. Anim. Sci. 86, 1-16.

Signorelli, F., Orru, L., Napolitano, F., De Matteis, G., Carmela Scata, M., Catillo, G., Marchitelli, C. \& Moioli, B., 2009. Exploring polymorphisms and effects on milk traits of the DGAT1, SCD1 and GHR genes in four cattle breeds. Livest. Sci. 125, 74-79.

Silva, L.F., Vandehaar, M.J., Weber Nielsen, M.S. \& Smith, G.W., 2002. Evidence for a local effect of leptin in bovine mammary gland. J. Dairy Sci. 85, 3277-3286.

Suchoki, T., Komisarek, J. \& Szyda, J., 2010. Testing candidate gene effects on milk production traits in dairy cattle under various parameterizations and modes of inheritance. J. Dairy Sci. 93, 2703-2717.

Szyda, J. \& Komisarek, J., 2007. Statistical modeling of candidate gene effects on milk production traits in dairy cattle. J. Dairy Sci. 90, 2971-2979.

Taniguchi, M., Utsugi, T., Oyama, K., Mannen, H., Kobayashi, M., Tanabe, Y., Ogino, A. \& Tsuji, S., 2004. Genotype of stearoyl-CoA desaturase is associated with fatty acids composition in Japanese Black cattle. Mamm. Genome 14, 142-148.

Tantia, M.S., Vijh, R.K., Mishra, B.P., Mishra, B., Kumar, S.T. \& Sodhi, M., 2006. DGAT1 and ABCG2 polymorphism in Indian cattle (Bos indicus) and buffalo (Bubalus bubalis) breeds. BMC Vet. Res. 2, 32.

Tartaglia, L.A., 1997. The leptin receptor. J. Biol. Chem. 272, 6093-6096.

Yeh, F.C., Yang, R.T.J. \& Xiyan, J.M., 2000. PopGene32. Microsoft Window-based Freeware for Population Genetic Analysis, Version 1.32 (Software). University of Alberta, Edmonton, AB. 